\title{
WIEDZA POLITYCZNA POLAKÓW W PERSPEKTYWIE PORÓWNAWCZEJ
}

\author{
POLITICAL KNOWLEDGE IN POLAND \\ IN COMPARATIVE PERSPECTIVE
}

Mikołaj Cześnik*, Michał Wenzel**

\begin{abstract}
ABSTRAKT
Celem artykułu jest porównawcza analiza wiedzy politycznej Polaków na tle społeczeństw w zbliżonym kontekście społeczno-politycznym i kulturowym. Kwestia wiedzy politycznej jest istotnym czynnikiem decydującym o jakości demokracji. Jest to także istotna zmienna wyjaśniająca w empirycznych badaniach politycznych postaw i zachowań. Zgodnie z teorią wiedza o polityce pozwala w oświecony sposób myśleć o wspólnocie i jej sprawach. Powinna ułatwiać obywatelom podejmowanie racjonalnych i roztropnych decyzji. Ma wpływ na postawy polityczne i zachowania, powinna uodparniać na populizm i ułatwiać występowanie $\mathrm{w}$ roli światłego obywatela. Nasze analizy pokazują relatywnie niski poziom wiedzy politycznej w Polsce, w porównaniu z krajami europejskimi o dłuższym trwaniu demokracji. Jednocześnie jednak Polska nie odbiega od innych krajów postkomunistycznych.
\end{abstract}

Słowa kluczowe: wiedza polityczna, Europa, głosowanie, porównawcze nauki polityczne
The article is a comparative analysis of political knowledge in Poland against the background of polities operating in a similar socio-political and cultural context. Political knowledge is an important determinant of the quality of democracy. It is also a key variable predicting attitudes and behaviour. According to theory, knowledge of politics allows for enlightened consideration of public affairs. It should make it easier for citizens to make rational decisions. It should also make them immune to populism and allow them to fully exercise civic roles. Our analyses show a relatively low level of political knowledge in Poland, as compared to the European countries with longer duration of democracy. At the same time, however, Poland does not diverge from other post-communist countries.

Keywords: political knowledge, Europe, voting, comparative political science

\footnotetext{
* Uniwersytet SWPS, Wydział Nauk Humanistycznych i Społecznych.

** Uniwersytet SWPS, Wydział Nauk Humanistycznych i Społecznych.
} 


\section{WSTĘP}

Celem niniejszego artykułu jest porównawcza analiza wiedzy politycznej Polaków. Chcemy się w nim dowiedzieć, co Polacy wiedzą o polityce i - przede wszystkim - jak pod względem tej wiedzy różnią się (ewentualnie) od obywateli innych krajów. Doniesienia prasowe i publicystyczne dyskusje w naszym kraju pełne są narzekań na ignorancję Polaków, ich niewiedzę, niski poziom zainteresowania i zorientowania w sprawach publicznych. Często w tych (domniemanych) wadach i niedostatkach polskich obywateli poszukuje się wyjaśnień stanu polskiej polityki, sytuacji na polskiej scenie politycznej. Warto więc na pewno tę problematykę porządnie zbadać, dostarczyć sprawdzonych, systematycznie zebranych i rygorystycznie zanalizowanych informacji. Z tego powodu pragniemy spojrzeć na wiedzę polityczną Polaków w szerszej, porównawczej perspektywie. Chcemy sprawdzić, czy polscy obywatele rzeczywiście są pod względem wiedzy (i niewiedzy) wyjątkowi, czy też nasze problemy i bolączki są w demokracji czymś normalnym, typowym, czymś, z czym borykają się wszystkie demokratyczne wspólnoty na świecie lub przynajmniej ich większość.

Omawiane zagadnienie jest dla polskich nauk społecznych nowe, nie dysponujemy bowiem porównawczymi analizami wiedzy politycznej Polaków. To zagadnienie badane było jedynie sporadycznie, w polskim piśmiennictwie socjologicznym i politologicznym refleksja na ten temat pojawiała się rzadko, wręcz wyjątkowo. Problematyka wiedzy politycznej w postkomunistycznej Polsce doczekała się jedynie kilku, i to dość wyrywkowych, niesystematycznych opracowań (Raciborski, 2011; Tworzecki, Markowski, 2011; Kunovich, 2013; Żerkowska-Balas, 2017). Systematycznych badań empirycznych o porównawczym charakterze nie prowadzono w ogóle. To fakt dodatkowo motywujący do podjęcia tej akurat problematyki badawczej.

Kwestia wiedzy politycznej jest dla demokracji niesłychanie istotna. To ważna w analizie politologicznej i socjologicznej kategoria; to także istotna zmienna wyjaśniająca w empirycznych badaniach politycznych postaw i zachowań. Zgodnie z teorią pozwala w „oświecony sposób” (por. Dahl, 1995) myśleć o wspólnocie i jej sprawach. Powinna ułatwiać obywatelom podejmowanie racjonalnych i roztropnych decyzji. Ma wpływ na postawy polityczne i zachowania, powinna stanowić barierę przed populizmem i ułatwiać występowanie w roli świadomego obywatela.

Z tych powodów uważamy, że badanie wiedzy politycznej Polaków, a przede wszystkim tego, jak się oni pod tym względem różnią od innych społeczeństw, 
może wzbogacić refleksję nad polską polityką i pozwoli ją lepiej rozumieć. Chcemy więc niniejszym artykułem zapełnić pewną lukę w polskim piśmiennictwie socjologicznym i politologicznym. Artykuł powstał w ramach projektu poświęconego badaniu wiedzy politycznej Polaków ${ }^{1}$. Ma on dostarczyć całościowego, systematycznego opisu zjawiska we współczesnej Polsce, uzupełnić deficyty wiedzy o polskim społeczeństwie, o zachodzących w nim procesach społecznych i politycznych, a także o politycznych, przede wszystkim wyborczych, zachowaniach Polaków.

Pierwsza część artykułu przedstawia tło teoretyczne naszej analizy, inspirujące nas studia i badania, a także podstawową siatkę pojęciową, którą posługujemy się w empirycznej części pracy. W drugiej części prezentujemy nasze pytania badawcze i hipotezy, poddawane w dalszych częściach artykułu testowi empirycznemu. W kolejnej, trzeciej części artykułu zajmujemy się kwestiami metodologicznymi, omawiamy sposoby konceptualizacji i operacjonalizacji problemu badawczego. Czwarta część zawiera analizy empiryczne. Ostatnia, piąta część zawiera podsumowanie i dyskusję wyników, ich interpretacje oraz płynące $\mathrm{z}$ nich wnioski. $\mathrm{W}$ aneksie przedstawiamy analizowane dane.

\section{TŁO TEORETYCZNE}

Nasze myślenie o wiedzy politycznej Polaków (rozpatrywanej w perspektywie porównawczej) pozostaje niewątpliwie pod silnym wpływem dokonań światowej refleksji nad polityką, przede wszystkim badań empirycznych nad wyborami i zachowaniami wyborczymi. To właśnie w tej subdyscyplinie nauk społecznych wiedza polityczna najczęściej pojawia się jako istotna kategoria wyjaśniająca procesy i zjawiska polityczne, a także jako ważna zmienna zależna, której analiza ma kluczowe znaczenie dla zrozumienia współczesnej polityki. Dlatego najistotniejszą inspiracją teoretyczną dla naszej analizy jest bogate piśmiennictwo poświęcone zachowaniom politycznym, ich determinantom i korelatom, wśród których wiedza polityczna zajmuje poczesne miejsce. Badania nad tą tematyką były i są prowadzone od dawna. Dotyczą one jednak głównie dojrza-

1 Projekt badawczy „Wiedza polityczna w Polsce” (2013-11-B-HS5-035459), finansowany przez Narodowe Centrum Nauki w ramach konkursu Opus 6, realizowany jest w Instytucie Nauk Społecznych Uniwersytetu SWPS. 
łych demokracji, wiedza polityczna w nowych, konsolidujących się, kruchych demokracjach jest analizowana o wiele rzadziej.

Omawiana literatura, mająca największy wpływ na nasze myślenie o omawianym fenomenie, dostrzega silne związki między wiedzą polityczną a partycypacją wyborczą. Manifestują się one zarówno na poziomie teorii (proponowane modele zachowań wyborczych akcentują dużą rolę wiedzy politycznej w decyzji wyborczej), jak i na poziomie empirycznym (wyniki badań potwierdzają przewidywane teorią zależności, wiedza polityczna okazuje się być istotną determinantą głosowania). To silne „utożsamienie” wiedzy politycznej z poziomem partycypacji wyborczej, które niektórzy uznają za dyskusyjne, wynika głównie z silnego wpływu wywieranego na współczesne badania nad zachowaniami wyborczymi przez teorię racjonalnego wyboru (o której więcej piszemy poniżej), dla której kwestia informacji jest zupełnie kluczowa. Znaczenie ma też prawdopodobnie wspomniany dorobek empiryczny tychże badań, który trudno ignorować, i który wyraźnie pokazuje, że wiedzę polityczną i partycypację wyborczą łączą - co do zasady - silne i trwałe związki.

$\mathrm{W}$ omawianych projektach badawczych wiedza polityczna jest pojęciem dobrze zdefiniowanym, skonceptualizowanym i zoperacjonalizowanym. Piśmiennictwo poświęcone temu zagadnieniu jest bogate (por. Delli Carpini, Keeter, 1996; Alvarez, 1997), posługują się nim duże porównawcze badania politologiczne; będący światowym kanonem w badaniach nad wyborami projekt "Comparative Study of Electoral Systems” (CSES) od swego zarania zadaje w swych kwestionariuszach pytania o polityczną wiedzę. Jest w nich ona rozumiana jako: „[...] zbiór faktów o polityce przechowywany w pamięci długotrwałej" (Delli Carpini, Keeter, 1996). Tak definiowana wiedza jest obywatelom niezbędna do najszerzej rozumianego uczestnictwa w demokracji; od obywatela oczekuje się wręcz, że będzie o sprawach wspólnoty dobrze poinformowany (por. Berelson, Lazarsfeld, McPhee, 1954). Ta definicja jest i nam bliska; rozumiemy i definiujemy roboczo wiedzę polityczną jako „przyswojoną informację o polityce”. Przymiotnik „przyswojona” oznacza tu informację ugruntowaną, nieulotną, zapamiętaną, zrozumianą (do pewnego przynajmniej stopnia), intelektualnie oswojoną. Zaś „polityka” jest przez nas roboczo definiowana szeroko, jako całokształt procesów i zjawisk zachodzących w sferze publicznej, a związanych głównie $\mathrm{z}$ dystrybucją władzy. W tym sensie wiedza polityczna powinna obejmować wiedzę czysto faktograficzną (historyczną, geograficzną, dotyczącą aktorów itd.), znajomość reguł gry rządzących zjawiskami i procesami 
politycznymi, świadomość grupowych interesów, sposobów ich realizacji, a także ich skutków. Ta nasza robocza definicja nie jest oczywiście oryginalna, opieramy się na dokonaniach klasyków badań nad wiedzą o polityce (por. Delli Carpini, Keeter, 1996).

Źródłem teoretycznej inspiracji są też dla nas pozostałe dokonania głównego nurtu empirycznie zorientowanej socjologii polityki i politologii. Wątek wiedzy o polityce pojawia się oczywiście w teorii racjonalnego wyboru, badacze reprezentujący tę perspektywę już od czasów Downsa (1957) uwzględniają wiedzę polityczną w swoich analizach głosowania, choć robią to na różne sposoby (por. Riker, Ordeshook, 1968; Rabinowitz, Macdonald, 1989; Grofman, 1995, Alvarez, 1997). Także badacze nawiązujący do tradycji Columbia School (por. Lazarsfeld, Berelson, Gaudet, 1944; Berelson, Lazarsfeld, McPhee, 1954), a także ci, którzy idą tropem dokonań Michigan School (por. Cambell, Kahn, 1952; Cambell, Converse, Miller, Stokes, 1960), często uwzględniają tematykę wiedzy politycznej w swoich analizach. Wszystkie te tropy teoretyczne obecne są w myśleniu o wiedzy politycznej badaczy z projektu CSES, do którego - na różne sposoby - odwołujemy się w niniejszym tekście.

Ważną inspiracją teoretyczną dla naszego artykułu jest piśmiennictwo z zakresu teorii demokracji. Warto tu przede wszystkim wymienić propozycje teoretyczne Dahla (1995, 2000). W jego wizji najważniejszą, wręcz konstytutywną zasadą ustroju demokratycznego jest polityczna równość (por. Dahl 1995). Jej zagwarantowaniu służyć mają kryteria procesu demokratycznego, łączne ich spełnienie pozwala wspólnotę lub stowarzyszenie uznać za rządzone demokratycznie. Do owych kryteriów Dahl zalicza rzeczywiste uczestnictwo, równe prawo głosu, oświecone rozumienie, nadzór nad podejmowanymi zadaniami oraz inkluzję dorosłych. O oświeconym rozumieniu mówimy wówczas, gdy obywatele mają wiedzę na temat spraw wspólnoty. Definiuje się je jako sytuację, w której: „[...] każdy członek musi mieć równe i rzeczywiste możliwości poinformowania się o różnych możliwych decyzjach i ich prawdopodobnych konsekwencjach" (Dahl, 2000). Wskaźnikiem oświeconego rozumienia jest poziom politycznej wiedzy członków wspólnoty demokratycznej - jej obywateli. Sartori (1994) zaś dodaje, że deficyty wiedzy mogą mieć dalekosiężne i brzemienne w skutki konsekwencje.

W końcu istotnym punktem odniesienia dla naszej analizy są dokonania i ustalenia badań empirycznych nad wiedzą o polityce; na jej temat wiemy już całkiem sporo, ten dość bogaty dorobek można streścić w kilku najważniejszych 
punktach. Po pierwsze, ogólny poziom wiedzy politycznej jest we współczesnych demokracjach ${ }^{2}$ raczej niski (Delli Carpini, Keeter, 1996; Toka, Popescu, 2008). Po drugie, wiedza polityczna jest zróżnicowana, społeczeństwa, społeczności czy grupy różnią się poziomem wiedzy na różne tematy (Delli Carpini, Keeter, 1996). Poziom wiedzy jest pozytywnie skorelowany z wykształceniem, wyższą pozycją społeczną, intensywną „konsumpcją mediów” i „politycznym wyrobieniem". Po trzecie, wiedza polityczna zdaje się być zasadniczo stabilna w czasie (por. Galston, 2007). Ten jej aspekt, odnotowany także w innych badaniach (por. Anduiza, Marinova, 2014; choć te autorki wskazują też na czynniki, które wywołują zmiany poziomu wiedzy politycznej w czasie), jest dla nas wyjątkowo istotny, szczególnie ze względu na pytania badawcze, które stawiamy sobie w tym artykule. Po czwarte w końcu, wiedza polityczna jest brzemienna w skutki, ma ważne konsekwencje, wpływa na głosowanie, stosunek do systemu, zadowolenie z demokracji, poczucie politycznego sprawstwa itp. (por. Bartels, 1996; Delli Carpini, Keeter, 1996; Fishkin, 1997; Gilens, 2001; Galston, 2007; Toka, Popescu, 2008). Część badaczy dowodzi, że podniesienie wiedzy politycznej może zmieniać wyniki wyborów; lepiej poinformowani wyborcy głosowaliby odmiennie. Inni wykazują, że osoby wiedzące więcej na tematy polityczne mają tendencję do bardziej spójnych i stabilnych postaw politycznych. Jeszcze inni pokazują, że ci obywatele, którzy są należycie poinformowani, są jednocześnie bardziej skłonni do uczestnictwa w polityce i mniej skłonni do politycznej alienacji, a także wykazują się większym przywiązaniem do wartości demokratycznych.

\section{PYTANIE BADAWCZE, HIPOTEZY, SCHEMAT ANALIZY, DANE}

W artykule tym zajmujemy się zagadnieniem nowym, do tej pory właściwie niebadanym - wiedzą polityczną Polaków w perspektywie porównawczej. Chcemy się przede wszystkim dowiedzieć, czy (i ewentualnie jak) Polacy różnią się pod względem tej wiedzy od innych społeczeństw. Nasze pytanie badawcze dotyczy poziomu wiedzy politycznej Polaków, w porównaniu z poziomem wiedzy odnotowywanym w innych społeczeństwach, w innych kontekstach

2 Mowa tu o demokracjach, bo o systemach niedemokratycznych prawie nic nie wiemy. Prowadzenie wszelkich badań społecznych $\mathrm{w}$ tych systemach jest $\mathrm{z}$ reguły utrudnione lub po prostu niemożliwe. Bardzo rzadko udaje się więc zdobyć odpowiednie dane. Zagadnienie wiedzy politycznej w systemach niedemokratycznych pozostaje więc fascynujące, ale trudne lub niemożliwe do empirycznego zbadania. 
instytucjonalnych, kulturowych, gospodarczych. Interesuje nas też rola czy znaczenie wiedzy politycznej w szeroko rozumianym procesie politycznym, i to zarówno w perspektywie mikro, jak i makro. Chcemy się zająć determinantami i skutkami wiedzy politycznej (na poziomie indywidualnym), a przede wszystkim zróżnicowaniem relacji między tym rodzajem wiedzy i innymi ważnymi zmiennymi społeczno-politycznymi poziomu mikro (czy Polacy są tu wyjątkowi, czy podobni do obywateli innych krajów?). Interesują nas też instytucjonalne, historyczne i kulturowe uwarunkowania wiedzy, to, jak kontekstowe charakterystyki wpływają na wiedzę o polityce. Zajmujemy się więc porównaniem systemów, analizą zależności na poziomie makro między wiedzą (zagregowaną) a innymi charakterystykami systemowymi.

Nasze pytanie badawcze ma oczywiście wymiar bardziej uniwersalny. Polska jest młodą demokracją, wciąż nieskonsolidowaną, ponadto przeżywającą właśnie dość turbulentny okres (co jest zresztą coraz bardziej charakterystyczne dla demokracji europejskich, szczególnie naszego regionu). W związku z tym nasze plany badawcze, a potem nasze ustalenia empiryczne, wpisują się w ogólniejsze rozważania na temat związków między wiedzą polityczną i demokracją, jej stanem. W tym sensie nasz projekt lokuje się między wyjaśnianiem idiograficznym i nomotetycznym: analizując sytuację Polaków w perspektywie porównawczej i podejmując refleksję nad ich (ewentualną) odmiennością, będziemy musieli chcąc nie chcąc - wypowiedzieć się też na temat ogólniejszych zależności między wiedzą o polityce i demokracją.

Warto podkreślić, że nasza analiza ma charakter statyczny. Nie zadajemy pytań o stabilność wiedzy w czasie (bądź jej zmiany) i o stabilność (ewentualnego) zróżnicowania międzykrajowego pod tym względem. Nasza analiza nie ma więc charakteru podłużnego. Zastosowany przez nas schemat badania ma przede wszystkim związek z dostępnością danych; dane CSES, z których korzystamy, nie nadają się do porównań w czasie. Dlatego nasza analiza musi mieć ograniczony w czasie, statyczny charakter (ale oczywiście zdajemy sobie sprawę z konieczności wykonania w przyszłości badań porównawczych, które czynnik czasu będą uwzględniać).

Nasza analiza jest rodzajem badawczego zwiadu. Podjęta przez nas tematyka jest nowa, więc celem badania jest wstępne rozpoznanie wiedzy politycznej Polaków w perspektywie porównawczej. Ten fakt ogranicza możliwości dedukcyjnego trybu działania, zmusza do częstszego stosowania strategii i rozumowań indukcyjnych. Mimo to, zgodnie z wymogami metodologicznej poprawności badania naukowego, stawiamy bardziej szczegółowe, testowalne hipotezy, doty- 
czące wiedzy politycznej Polaków w perspektywie porównawczej i zróżnicowania wiedzy politycznej we współczesnym świecie. Oczywiście nie abstrahują one od teoretycznego i empirycznego dorobku nauk społecznych, od dotychczas wykonanych analiz.

Spodziewamy się, że poziom wiedzy politycznej Polaków, podobnie jak obywateli innych niedojrzałych, konsolidujących się demokracji, będzie niższy niż poziom wiedzy obywateli demokracji dojrzałych, skonsolidowanych, trwałych. Ta hipoteza nawiązuje do bogatej literatury z zakresu teorii demokracji (por. Linz, Stepan, 1996) i sugeruje, że postępująca demokratyzacja i następująca po niej demokratyczna konsolidacja powinna oznaczać wzrost wiedzy politycznej. Praktykujący demokrację obywatele pogłębiają bowiem swoją kompetencję w kwestiach publicznych, są informowani o sprawach wspólnoty, zdobywają wiedzę o funkcjonowaniu demokratycznego systemu, o regułach, mechanizmach, aktorach. Uczą się funkcjonowania zasad demokracji, więc po jakimś czasie ich wiedza polityczna wzrasta. Wywód ten opiera się na mocnym (i naszym zdaniem w pełni zasadnym) założeniu ${ }^{3}$, że obywatele krajów niedemokratycznych, wchodzących na drogę demokratyzacji, mają na początku transformacji ustrojowej niewielką (lub wręcz żadną) wiedzę na temat demokratycznej polityki, jej reguł, mechanizmów, aktorów itd.

Hipotezę tę będziemy testować, porównując poziom wiedzy politycznej Polaków z poziomem tejże wiedzy odnotowywanym wśród obywateli innych krajów, o odmiennych systemach politycznych. Technicznie rzecz biorąc, w pierwszej części analiz empirycznych zajmiemy się porównaniem wartości indeksu wiedzy politycznej w poszczególnych krajach, a także (ewentualną) zależnością, korelacją między zagregowanym poziomem wiedzy politycznej i zaawansowaniem demokracji, jej dojrzałością (operacjonalizowaną jako długość trwania systemu). W drugiej części analiz empirycznych będziemy sprawdzać, czy zależności między wiedzą polityczną a innymi ważnymi zmiennymi społeczno-politycznymi są w poszczególnych krajach takie same, czy też różne, i czy ewentualne różnice mają jakiś systemowy, nieprzypadkowy, zgodny z teorią charakter.

Analizie poddajemy wiedzę polityczną w okresach okołowyborczych, bo wtedy - zasadne jest zakładać - jest ona najwyższa, najsilniej wykrystalizowana i najbardziej obywatelom potrzebna (by mogli podjąć racjonalną decyzję).

3 Wyczerpujące omówienie tego założenia (tabula rasa approach) i jego implikacji w kontekście demokratyzującego się systemu można odnaleźć w innym miejscu (por. Cześnik, Żerkowska-Balas, Kotnarowski, 2013). 
Zbiór danych projektu CSES daje unikalną możliwość przeprowadzania analiz porównawczych, będących wszak podstawową metodą empirycznej weryfikacji hipotez w badaniach politologicznych (por. Shively, 2001). Istotnym dla badań porównawczych zagadnieniem jest problem funkcjonalnej ekwiwalentności analizy. Słomczyński (1995) omawia trzy jej rodzaje: przedmiotową, pomiarową i temporalno-procesualną. W danych CSES mamy do czynienia ze wszystkimi trzema typami problemów; omówiony poniżej dokładniej Moduł 4 jest reakcją na te problemy i próbą poradzenia sobie z nimi.

W kwestionariuszach CSES pytania o wiedzę polityczną były zadawane od pierwszej edycji projektu. W pierwszych trzech modułach stosowano strategię zaproponowaną przez klasyków badań nad wiedzą polityczną (por. Delli Carpini, Keeter, 1993), która polega na zadawaniu odmiennych pytań, różniących się treściowo, ale takich samych (podobnych, funkcjonalnie ekwiwalentnych), jeśli chodzi o zróżnicowanie/rozproszenie poprawnych odpowiedzi w populacji. Starano się takie podobne rozkłady osiągnąć, instruując lokalnych badaczy, aby zadawali w wywiadzie trzy pytania: jedno takie, na które prawidłową odpowiedź znają dwie trzecie populacji, jedno takie, na które prawidłową odpowiedź zna połowa populacji, i jedno takie, na które prawidłową odpowiedź zna jedna trzecia populacji. Analizy empiryczne wskazują, że to podejście nie daje w pełni zadowalających efektów (por. Elff, 2009); na przykład w Module 2 tylko siedem krajów osiągnęło pożądany rozkład poprawnych odpowiedzi. W związku z tym w Module 4 zastosowano inną strategię: we wszystkich krajach zdecydowano się zadać te same cztery pytania: pytanie o nazwisko ministra finansów (aktualnie sprawującego funkcję w badanym kraju), pytanie o partię lub ugrupowanie, które zajęło drugie miejsce w wyborach (ostatnio w danym kraju przeprowadzonych), pytanie o poziom stopy bezrobocia w danym kraju i pytanie o nazwisko Sekretarza Generalnego ONZ. Ta strategia również obarczona jest poważnymi niedoskonałościami: poziom bezrobocia jest bardziej lub mniej stabilny, na pytanie o partie polityczne łatwiej jest odpowiedzieć w krajach o ordynacji większościowej niż proporcjonalnej itd.

Optymalizując strategię analityczną, w artykule korzystać będziemy zarówno z Modułu 3, jak i Modułu 4, porównując i niejako triangulując wyniki. Do porównań międzynarodowych stosujemy dane z Modułu 4 (są to dane porównywalne pomiędzy krajami), natomiast do analizy czynników różnicujących wiedzę - dane zebrane w Module 3. Szczegółowe wyjaśnienia specyfiki danych $\mathrm{z}$ poszczególnych modułów zawarte są $\mathrm{w}$ aneksie. 


\section{ANALIZY EMPIRYCZNE}

Analizy empiryczne rozpoczynamy od porównawczego umiejscowienia społeczeństwa polskiego na tle świata, jeśli chodzi o poziom wiedzy politycznej. Jednym z naszych roboczych założeń jest przypuszczenie, że wiedza polityczna jest zasobem akumulowanym przez wspólnotę polityczną międzypokoleniowo, w powolnym procesie budowania instytucji (rozumianych szeroko, socjologicznie). Sądzimy więc, że trwałość i dojrzałość instytucji demokratycznych, mierzona wiekiem demokracji (operacjonalizowanym tu jako liczba lat, które upłynęły od demokratycznego przejścia), sprzyja lepszej orientacji w sprawach polityki (mierzonej na poziomie zagregowanym jako krajowa średnia indeksu prawidłowych odpowiedzi na pytania o wiedzę polityczną).

Wykres 1. pokazuje zależność pomiędzy długością trwania systemu demokratycznego a poziomem wiedzy politycznej. Okazuje się, że ta zależność jest na poziomie zagregowanym słaba, współczynnik korelacji (R Pearsona) między dwiema analizowanymi zmiennymi wynosi 0,05 . Zależność ma jednak przewidywany naszą tezą kierunek, w krajach „demokratycznie dojrzalszych” średnia wiedza polityczna jest wyższa. Oczywiście ten wynik może mieć związek z charakterem użytych wskaźników i ich jakością, a także z liczebnością i składem próby (w badaniu uwzględniono nielosową jednak próbę krajów uczestniczących w projekcie CSES, w jego konkretnym module). Interesująca nas najbardziej Polska, przy niewielkim stażu swego systemu demokratycznego, sytuuje się

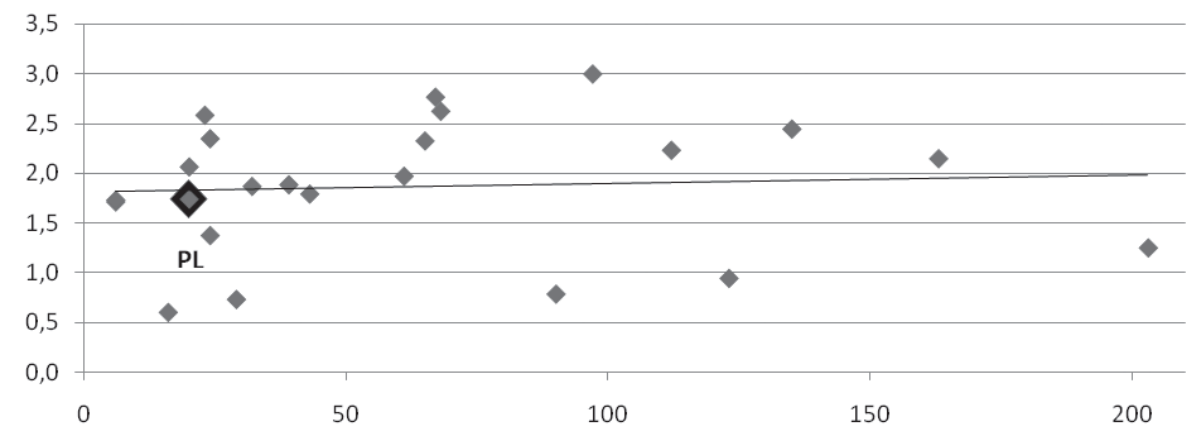

Wykres 1. Wiedza polityczna w świecie a długość trwania demokracji

Źródło: CSES4. Wiedza polityczna na skali pięciostopniowej (wartości od 0 do 4). Jest to średnia liczba poprawnych odpowiedzi na 4 pytania o wiedzę (oś pionowa). Trwanie demokracji w latach (oś pozioma). 
w okolicach środka rankingu, uzyskując wyższe wyniki niż na przykład tak stare demokracje jak USA czy Kanada.

W dalszej części analizy pomijamy wyniki z krajów pozaeuropejskich. Domniemywamy, że czynniki kontekstualne mają znaczenie dla kształtowania poziomu i zróżnicowania wiedzy politycznej. Porównując wyniki i określając czynniki mogące wpływać na wiedzę, musimy maksymalnie ograniczyć możliwy wpływ specyfiki lokalnej. Z tego też powodu w dalszej części analizy koncentrujemy się na krajach europejskich; krajów pozaeuropejskich, odmiennych bądź skrajnie odmiennych pod względem kulturowym czy religijnym, w badaniu nie uwzględniamy ${ }^{4}$.

Wykresy 2. i 3. pokazują poziom wiedzy politycznej w Europie. Na wykresie 2. przedstawione są wartości średnie dla poszczególnych krajów, natomiast na wykresie 3. uwidocznione są średnie dla Europy zachodniej ${ }^{5}$, wschodniej ${ }^{6}$ (bez Polski) oraz osobno dla Polski. Nasza robocza hipoteza o ułomności w stosunku do skonsolidowanych demokracji europejskich - wiedzy politycznej w Polsce wydaje się znajdować pewne potwierdzenie $\mathrm{w}$ analizowanych przez nas danych (por. wykres 2). Średni jej poziom (mierzony średnią poprawnych odpowiedzi na cztery zadane w sondażu pytania) jest znacząco wyższy w krajach umownie nazwanych przez nas Europą zachodnią niż w Polsce, która z kolei nie różni się pod tym względem od innych krajów postkomunistycznych. Wyniki wskazują więc na istotność braków w edukacji demokratycznej obywateli państw dawnego bloku wschodniego: wiedzą o polityce (średnio rzecz biorąc) mniej, gdyż krócej praktykują demokrację, są mniej oświeceni w sprawach wspólnoty, funkcjonowania demokratycznego systemu, rządzących nim reguł, działających w nim mechanizmów i współzawodniczących tam aktorów. Warto jednak zauważyć, że zależność nie jest ścisła; dla części krajów postkomunistycznych uzyskane wyniki są relatywnie wysokie (Słowenia), a część starszych demokracji wykazuje niski poziom wiedzy (Francja, Irlandia).

4 Zbadanie wpływu czynników kulturowych na wiedzę polityczną, jej zróżnicowanie i relacje z innymi ważnymi zmiennymi społeczno-politycznymi jest fascynującym zadaniem badawczym, wartym porządnej, systematycznej i rygorystycznie przeprowadzonej analizy empirycznej. W niniejszym artykule nie ma na nią jednak miejsca.

5 Są nimi w tym badaniu CSES kraje członkowskie UE/EOG sprzed rozszerzenia UE w 2004: Austria, Francja, Grecja, Irlandia, Islandia, Niemcy, Norwegia, Portugalia, Szwajcaria, Szwecja.

6 Są nimi w tym badaniu CSES następujące kraje: Bułgaria, Czarnogóra, Czechy, Serbia, Słowenia. 


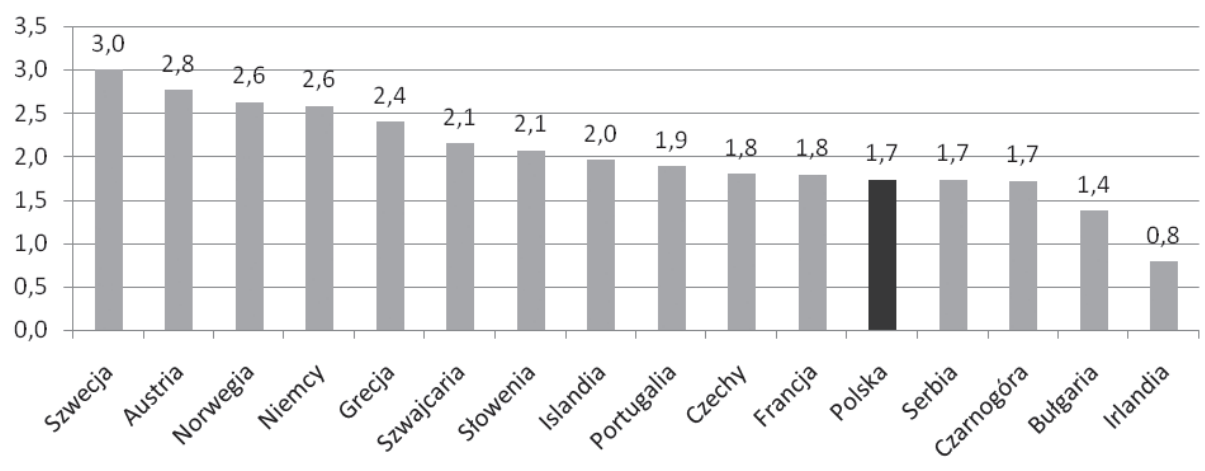

Wykres 2. Wiedza polityczna w Europie (wartości średnie w krajach)

Źródło: CSES4.

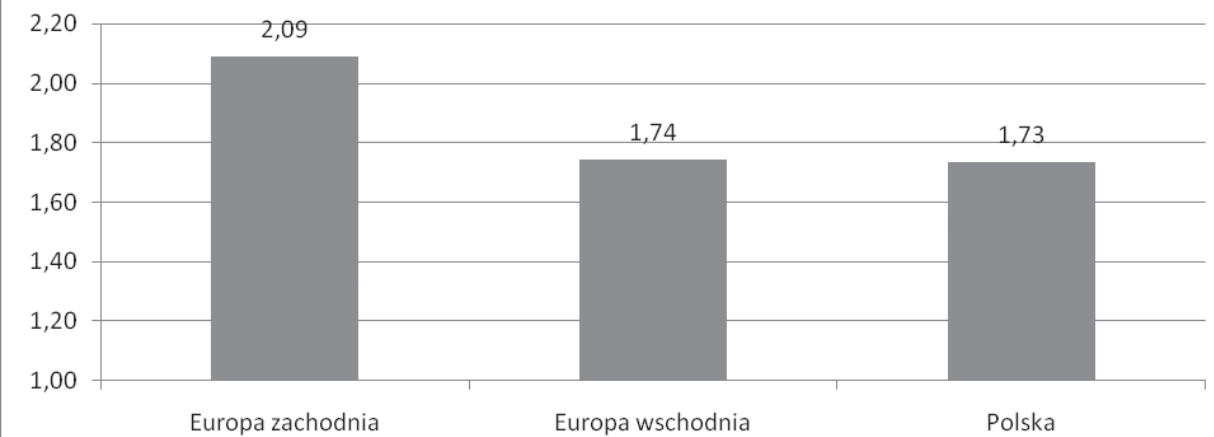

Wykres 3. Wiedza polityczna w Europie (wartości średnie)

Źródło: CSES4. Różnica średnich między Europą zachodnią a Polską istotna statystycznie na poziomie $\mathrm{p}<0,001$. Różnica średnich między Polską a Europą wschodnią nieistotna.

Kolejny etap analizy to eksploracja potencjalnych korelatów (determinant) wiedzy politycznej w Europie. Europejczycy są tu potraktowani jako zbiorowość nosząca cechy jednej wspólnoty politycznej. Założenie to uzasadnione jest charakterem związków politycznych między badanymi organizmami państwowymi (wszystkie należą do UE, są w trakcie negocjacji akcesyjnych bądź są połączone wieloraką siatką związków na poziomie politycznym, np. należą do Strefy Schengen, EOG itd.). W artykule nie traktujemy krajów Europy jako oddzielnych 


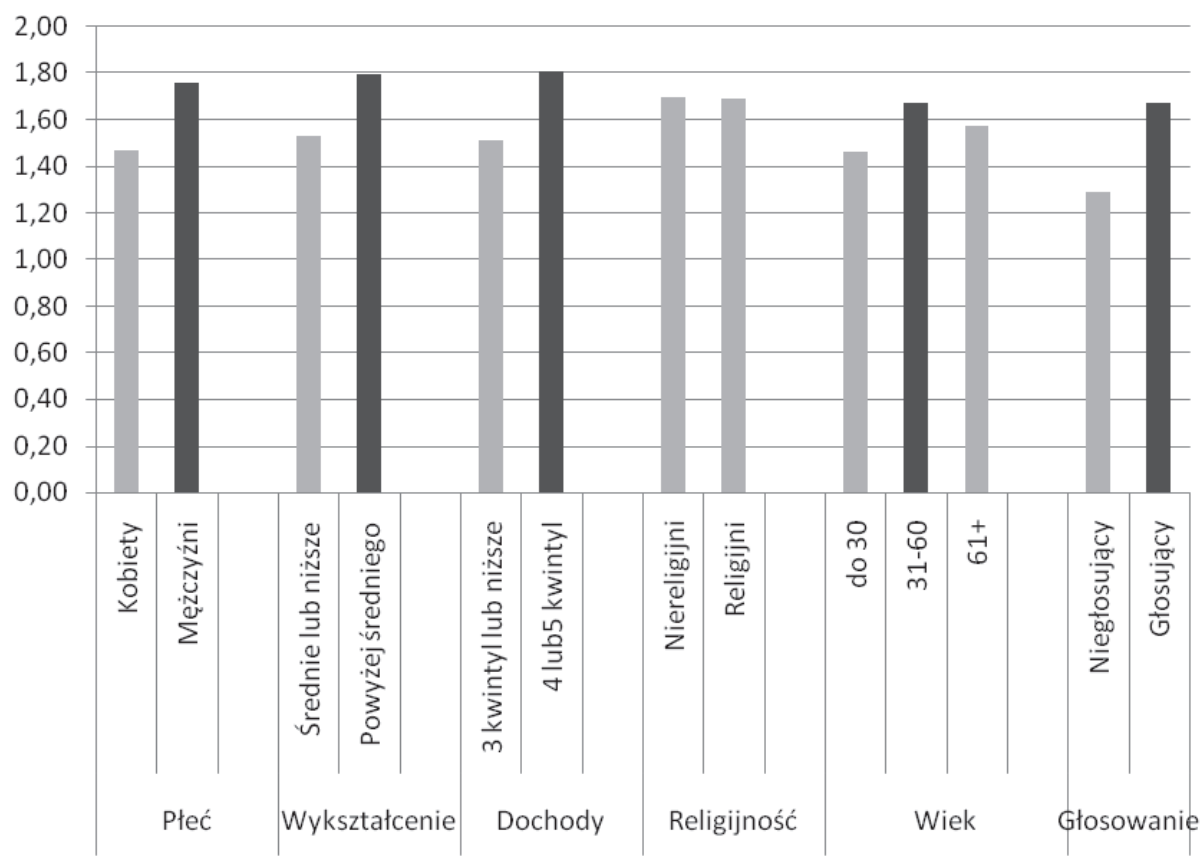

Wykres 4. Korelaty wiedzy politycznej w Europie (wartości średnie)

Źródło: CSES3. Różnice średnich istotne dla grup wyróżnionych ze względu na płeć, wykształcenie, dochody, wiek (para: do 30/31-60) i głosowanie ( $<<0,001)$. Różnice dla grup wyróżnionych ze względy na religijność nieistotne.

organizmów, lecz staramy się odkryć prawidłowości na poziomie „wspólnoty politycznej Europejczyków"?.

W analizach zbiorczo przedstawionych na wykresie 4. i w tabeli 1. porównujemy średnie wartości wiedzy politycznej, operacjonalizowanej jako indeks poprawnych odpowiedzi na pytania o wiedzę, w grupach wyróżnianych ze względu na płeć, wykształcenie, dochód, wiek, religijność i głosowanie. Te zmienne, zgodnie z piśmiennictwem, powinny w istotny sposób wpływać na

7 Instytucjonalne procesy jej kształtowania opisywali na przykład: Mannin (1999); Hughes, Sasse, Gordon (2004); Sedelmeier (2005); Schimmelfennig, Sedelmeier (2005); Zielonka (2006); Sissenich (2007). Ponadto przyjęcie założenia o istnieniu „wspólnoty politycznej Europejczyków” (i potraktowanie europejskiej części zbioru CSES jako choćby ułomnie reprezentatywnej dla tego demosu próby) ułatwia interpretację wyników przeprowadzonej analizy empirycznej i umożliwia wyprowadzenie pewnych ogólnych wniosków na temat analizowanych relacji. 
wiedzę polityczną. Wstępny ogląd danych pokazanych na wykresie 4 . w dużej mierze potwierdza hipotezy robocze. Jeśli chodzi o zmienne społeczno-demograficzne, poziom znajomości polityki jest znacząco wyższy wśród obywateli legitymujących się edukacją powyżej średniej. Majątek ma podobny, istotny wpływ na wiedzę; bogatsi wiedzą o polityce zdecydowanie więcej niż ubodzy. Mężczyźni zaś średnio wiedzą więcej na ten temat niż kobiety. Najwięcej wiedzą obywatele w średnim wieku.

Zmienne operacjonalizujące zaangażowanie polityczne i orientację światopoglądową częściowo wywierają wpływ w oczekiwanym przez nas kierunku. Zarysowuje się gigantyczna przepaść w znajomości polityki pomiędzy głosującymi w wyborach a niebiorącymi udziału w głosowaniu ${ }^{8}$. Religijność natomiast nie odgrywa znaczącej roli, zostanie więc pominięta w dalszych analizach.

Wiek ${ }^{9}$ różnicuje wiedzę jedynie w niektórych krajach. Pomijając tę zmienną, opisane powyżej relacje i zróżnicowania są w Europie niemal powszechne (por. tabela 1). W wielu krajach zaobserwowano komplet przewidywanych zależności. Są to: Chorwacja, Czechy, Dania, Francja, Hiszpania, Holandia, Islandia, Norwegia i Szwajcaria.

Tabela 1. Korelaty wiedzy politycznej w Europie

\begin{tabular}{|l|l|l|l|l|l|}
\hline & Płeć & Wykształcenie & Dochody & Wiek & Glosowanie \\
\hline Austria & & & & & \\
\hline Chorwacja & & & & & \\
\hline Czechy & & & & & \\
\hline Dania & & & & & \\
\hline Estonia & & & & & \\
\hline Finlandia & & & & & \\
\hline Francja & & & & & \\
\hline Grecja & & & & & \\
\hline Hiszpania & & & & & \\
\hline
\end{tabular}

8 W analizach relacji uczestnictwa wyborczego i wiedzy politycznej ścierają się dwa podejścia; jedni definiują wiedzę jako zmienną niezależną, jedną z najważniejszych determinant głosowania (Delli Carpini, Keeter, 1996); inni wskazują na istotną rolę, jaką zachowania polityczne (w tym głosowanie) odgrywają w procesie nabywania wiedzy o polityce (Plutzer, 2002), traktując tym samym wiedzę jako zmienną zależną. My w niniejszym artykule sięgamy po to drugie podejście.

9 Różnica między kategorią najmłodszych (do 30 lat) i osób w wieku średnim (31-60). 


\begin{tabular}{|l|l|l|l|l|l|}
\hline & Płeć & Wykształcenie & Dochody & Wiek & Glosowanie \\
\hline Holandia & & & & & \\
\hline Islandia & & & & & \\
\hline Irlandia & & & & & \\
\hline Łotwa & & & X & & \\
\hline Niemcy & & & & & \\
\hline Norwegia & & & & & \\
\hline Polska & & & & & \\
\hline Portugalia & & & & & \\
\hline Rumunia & & & & & \\
\hline Słowacja & & & & & \\
\hline Szwajcaria & & & & & \\
\hline Szwecja & & & & & \\
\hline
\end{tabular}

Pole białe: różnice średnich istotne na poziomie $\mathrm{p}<0,001$; pole szare: różnice średnich istotne na poziomie $\mathrm{p}<0,05$; pole czarne: różnice średnich nieistotne; $\mathrm{X}$ : brak danych

Źródło: CSES3.

Kolejnym krokiem w naszej analizie jest identyfikacja silnych (najistotniejszych statystycznie) determinant wiedzy politycznej. Służą do tego analizy wielozmiennowe. My stosujemy analizę regresji (model OLS). Jej wyniki (tabela 2.) pokazują, że cztery uwzględnione w modelu zmienne wyjaśniające (płeć, wykształcenie, dochody, głosowanie) mają niezależny od siebie, istotny statystycznie wpływ na poziom wiedzy politycznej, wiek natomiast (zmienna zero-jedynkowa, w której wyższe wartości oznaczają wiek średni, czyli 31-60 lat) nie jest istotnym czynnikiem. Uzyskane wyniki są zgodne z wynikami analiz dwuzmiennowych, przeprowadzonych wcześniej: mężczyźni wiedzą o polityce więcej od kobiet, poziom wiedzy jest wyższy wśród osób lepiej wykształconych, zamożniejszych i głosujących. Co więcej, każda z tych zmiennych wywiera na wiedzę polityczną istotny statystycznie wpływ niezależnie od pozostałych (ma na nią wpływ netto).

W kolejnym modelu testujemy kluczową dla naszego artykułu hipotezę o niezależnym wpływie „polskości” na poziom wiedzy politycznej. Prowadzimy analizy na całym zbiorze (ograniczonym jednak, o czym wspominaliśmy wcześniej, do krajów europejskich), a jedną ze zmiennych w modelu jest bycie Polakiem. W tak skonstruowanym modelu zmienna ta wpływa negatywnie na wiedzę polityczną; jeśli kontrolować pozostałe czynniki (przede wszystkim udział 
Tabela 2. Determinanty wiedzy politycznej w Europie

\begin{tabular}{|l|c|c|}
\cline { 2 - 3 } \multicolumn{1}{c|}{} & Model 1 & Model 2 \\
\cline { 2 - 3 } \multicolumn{1}{c|}{} & Beta & Beta \\
\hline Płeć $(\mathrm{f}=0, \mathrm{~m}=1)$ & $0,172^{* *}$ & $0,171^{* *}$ \\
\hline Wykształcenie & $0,118^{* *}$ & $0,115^{* *}$ \\
\hline Dochody & $0,113^{* *}$ & $0,115^{* *}$ \\
\hline Wiek & nieistotne & nieistotne \\
\hline Głosowanie & $0,194^{* *}$ & $0,188^{* *}$ \\
\hline Polska & & $-0,042^{* *}$ \\
\hline R2 & 0,115 & 0,117 \\
\hline
\end{tabular}

** istotne na poziomie $\mathrm{p}<0,001 ;{ }^{*}$ istotne na poziomie $\mathrm{p}<0,05$.

Źródło: CSES4. Model regresji liniowej (OLS). Zmienna zależna: wiedza polityczna.

w głosowaniu), Polacy wyróżniają się in minus, co potwierdza naszą hipotezę: są osobami (średnio rzecz biorąc) mniej wiedzącymi o polityce od obywateli innych, włączonych do analizy krajów europejskich. Trzeba jednak wyraźnie stwierdzić, że - choć statystycznie istotny - wpływ zamieszkiwania w Polsce jest niewielki.

Kolejnym elementem naszej analizy jest zbadanie, czy odnotowana przez nas zależność świadczy o polskiej wyjątkowości, czy też ma bardziej uniwersalny charakter: większa polityczna ignorancja jest cechą charakterystyczną dla wszystkich społeczeństw młodych, niedojrzałych demokracji. W celu sprawdzenia tej hipotezy przeprowadzamy analizę analogiczną jak wyżej omówiona, ale wyłącznie na danych pochodzących z krajów postkomunistycznych (tabela 3.). Jeśli bycie Polakiem wciąż będzie w statystycznie istotny sposób wpływać na zmienną zależną, to będzie to uprawniać do twierdzenia o wyjątkowości polskiej (nie) wiedzy o polityce. Jeśli zaś nie odnotujemy istotnego statystycznie związku, to będzie to wskazywać na bardziej uniwersalną, ogólniejszą ignorancję polityczną obywateli krajów byłego bloku komunistycznego.

W tak skonstruowanym modelu bycie Polakiem nie odgrywa żadnej roli, nie dodaje niczego do wartości modelu. Polacy mieszczą się idealnie w postkomunistycznej średniej. Konkludujemy więc, że niski stan wiedzy politycznej jest fenomenem regionalnym, nie zaś krajowym; to nie Polacy są wyjątkowymi ignorantami, ale raczej polityczna niewiedza jest czymś typowym dla nowych demokracji (przynajmniej tych europejskich). 
Tabela 3. Determinanty wiedzy politycznej w Europie postkomunistycznej

\begin{tabular}{|l|c|c|}
\cline { 2 - 3 } \multicolumn{1}{c|}{} & Model 1 & Model 2 \\
\cline { 2 - 3 } \multicolumn{1}{c|}{} & Beta & Beta \\
\hline Płeć $(\mathrm{f}=0, \mathrm{~m}=1)$ & $0,160^{* *}$ & $0,160^{* *}$ \\
\hline Wykształcenie & $0,133^{\star *}$ & $0,133^{\star *}$ \\
\hline Dochody & $0,118^{* *}$ & $0,117^{* *}$ \\
\hline Wiek & $0,038^{\star}$ & $0,038^{\star}$ \\
\hline Głosowanie & $0,193^{* *}$ & $0,193^{* *}$ \\
\hline Polska & & Nieistotne \\
\hline R2 & 0,116 & 0,116 \\
\hline
\end{tabular}

** istotne na poziomie $\mathrm{p}<0,001 ;{ }^{*}$ istotne na poziomie $\mathrm{p}<0,05$.

Źródło: CSES4. Model regresji liniowej (OLS). Zmienna zależna: wiedza polityczna.

\section{PODSUMOWANIE, DYSKUSJA WYNIKÓW}

Celem niniejszego artykułu jest porównawcza analiza wiedzy politycznej Polaków. Próbujemy w nim odpowiedzieć na pytanie, czy Polacy różnią się pod względem tej wiedzy od innych społeczeństw i - ewentualnie - jak się różnią. Porównujemy więc poziom wiedzy politycznej Polaków z poziomem wiedzy odnotowywanym w innych społeczeństwach, w innych kontekstach instytucjonalnych czy kulturowych. Analizujemy też znaczenie wiedzy politycznej $\mathrm{w}$ szeroko rozumianym procesie politycznym, przede wszystkim w wyborach.

Nasze ustalenia w dużej mierze potwierdzają wstępne przewidywania dotyczące rozkładu wiedzy politycznej w społeczeństwach europejskich. Zgodnie z przypuszczeniami, obywatele zaawansowanych, skonsolidowanych demokracji wiedzą więcej o krajowej i międzynarodowej polityce niż mieszkańcy krajów postkomunistycznych. Zasada ta znajduje odzwierciedlenie w Europie, niekoniecznie jednak daje się ekstrapolować na demokracje wyrosłe w innym kontekście kulturowym. Nasze wnioski mają stosunkowo ograniczony charakter i koncentrują się na zjawiskach zachodzących wewnątrz państw i społeczeństw europejskich, skupionych wokół projektu budowania wspólnych struktur instytucjonalnych.

Potwierdzają się zaobserwowane wcześniej i dość oczywiste zależności pomiędzy wiedzą o sprawach politycznych a szeroko rozumianą kompeten- 
cją poznawczą, a także pozycją społeczną. Czynniki takie jak wykształcenie i dochody korelują z bardzo wielu wskaźnikami używanymi w socjologii i ich istotność, jeśli chodzi o kształtowanie orientacji w świecie polityki, nie jest niczym zaskakującym.

Analizy pokazują, że kluczowym czynnikiem determinującym poziom wiedzy politycznej jest partycypacja wyborcza. W Polsce jest ona relatywnie niska, co nakłada się na specyfikę wschodnioeuropejską, skutkując obniżonym wobec rozwiniętych demokracji uświadomieniem czy oświeceniem obywateli w sprawach polityki. Wynik ten potwierdza - z jednej strony - słuszność publicystycznych tez o istotności wyborów jako czynnika edukacji społeczeństwa, a $\mathrm{z}$ drugiej - stanowi ostrzeżenie przed skutkami podziału społeczeństwa na czynnych i biernych politycznie. Zgodnie z naszymi przypuszczeniami obywatele nabywają informacje w procesie systematycznej konfrontacji wiedzy z działaniem, w tym przypadku głosowaniem. Otwarte jest pytanie o kierunek tej zależności: czy uświadomiony obywatel decyduje się pójść głosować, ponieważ jest świadomy wagi procesu politycznego, czy też odwrotnie - nabywa wiedzę decydując, jak zagłosować (instrumentalnie).

\section{ANEKS: ŹRÓDŁA DANYCH}

W artykule wykorzystaliśmy dane pochodzące $\mathrm{z}$ badania Comparative Study of Electoral Systems (CSES), moduł 3 i 4. Szczegółowe informacje na temat konceptualizacji, narzędzi badawczych, procedur i danych dostępne są na stronie internetowej projektu: www.cses.org. Zbiór danych CSES3 w wersji z 15 grudnia 2015; doi:10.7804/cses.module3.2015-12-15; zbiór danych CSES4 w wersji z 22 czerwca 2016; doi:10.7804/cses.module4.2016-06-22. Dane te uzyskano w oparciu o prace wspomagane finansowo przez American National Science Foundation (www.nsf. gov), granty nr SES-0817701, SES-1154687 i SES-1420973, GESIS - Leibniz Institute for the Social Sciences, the University of Michigan. Dane z Polski zebrano w ramach projektu PGSW (edycje 2005 i 2011).

Moduł 3 CSES realizowany był w latach 2006-2011. Użyto danych z następujących krajów: Austria, Chorwacja, Czechy, Dania, Estonia, Finlandia, Francja, Grecja, Hiszpania, Irlandia, Islandia, Łotwa, Holandia, Niemcy, Norwegia, Polska, Portugalia, Rumunia, Słowacja, Szwajcaria, Szwecja. Pytania o wiedzę polityczną były różne w poszczególnych krajach. W Polsce realizacja miała miejsce od listopada do grudnia 2007 metodą wywiadu osobistego wspieranego komputerowo (CAPI). 
Pytania o wiedzę zadane w Polsce brzmiały: 1) Do jakiego sojuszu wojskowego należy Polska? (odpowiedzi: Układ Warszawski; Układ Wyszehradzki; NATO; Trójkąt Weimarski; ANZUS); 2) Kto jest obecnie kanclerzem Republiki Federalnej Niemiec? (odpowiedzi: Helmut Kohl; Gerhard Schroeder; Angela Merkel; Hans Dietrich-Genscher; Edmund Stoiber; Konrad Adenauer); 3) Jaka instytucja orzeka w Polsce o zgodności ustaw z Ustawą Zasadniczą? (odpowiedzi: Sąd Najwyższy; Trybunał Stanu; Naczelny Sąd Administracyjny; Prokuratura Generalna; Trybunał Konstytucyjny; Minister Sprawiedliwości).

Moduł 4 realizowany był w latach 2011-2015. Dane pochodzą z następujących krajów europejskich (tabele 1. i 2., wykres 2. i 3.): Austria, Bułgaria, Czarnogóra, Czechy, Francja, Irlandia, Islandia, Niemcy, Norwegia, Polska, Portugalia, Serbia, Słowenia, Szwajcaria, Szwecja. W analizach przedstawionych w tabeli 3. użyto danych z następujących krajów: Bułgaria, Czarnogóra, Czechy, Polska, Serbia, Słowenia. W analizie przedstawionej na rysunku 1. uwzględniono dodatkowo dane z następujących krajów: Australia, Brazylia, Izrael, Japonia, Kanada, Korea Pd., Meksyk, Nowa Zelandia, Tajlandia, Tajwan, Turcja, USA. Pytania o wiedzę polityczną były takie same we wszystkich krajach. W Polsce realizacja miała miejsce od października do listopada 2011 metodą wywiadu osobistego wspieranego komputerowo (CAPI). Pytania o wiedzę brzmiały: 1) Która z niżej wymienionych osób była Ministrem Finansów bezpośrednio przed ostatnimi wyborami?; 2) Jaka jest stopa bezrobocia w Twoim kraju?; 3) Która partia zajęła drugie miejsce w ostatnich wyborach w Twoim kraju?; 4) Kto jest aktualnym sekretarzem generalnym Organizacji Narodów Zjednoczonych?

Dobór próby i metodologia przeprowadzenia wywiadu uwzględniały lokalną specyfikę: zarówno prawną, jak i kwestie logistyczne oraz ograniczenia instytucjonalne, a więc różniły się w poszczególnych krajach. Badanie jest w założeniu reprezentatywne dla ogółu wyborców (wspólnoty politycznej) danego państwa. Szczegółowe opisy doboru prób i metody przeprowadzenia wywiadu podane są na stronie internetowej projektu (http://www.cses.org/datacenter/download.htm).

\section{BibliOgRAFIA:}

Alvarez, M.R. (1997). Information and Elections. Ann Arbor: The University of Michigan Press.

Anduiza, E., Marinova, D. (2014). When Bad News is Good: Political Knowledge in Times of Crisis. Referat przedstawiony na ECPR Joint Sessions, 10-15 kwietnia, Salamanca. 
Bartels, L.M. (1996). Uninformed Votes: Information Effects in Presidential Elections. American Journal of Political Science, 40, s. 194-230.

Berelson, B.R., Lazarsfeld, P.F., McPhee, W.N. (1954). Voting: A Study of Opinion Formation in a Presidential Campaign. Chicago: University of Chicago Press.

Cambell, A., Kahn, R. (1952). The People Elect a President. Ann Arbor: University of Michigan Press.

Cambell, A., Converse, P.E., Miller, W.E., Stokes, D.E. (1960). The American Voter. New York: Wiley.

Dahl, R. (1995). Demokracja i jej krytycy. Kraków: Znak.

Dahl, R. (2000). O demokracji. Kraków: Znak.

Delli Carpini, M.X., Keeter, S. (1993). Measuring Political Knowledge: Putting First Things First. American Journal of Political Science, 37, s. 1179-1206.

Delli Carpini, M.X., Keeter, S. (1996). What Americans Know About Politics and Why It Matters. New Haven: Yale University Press.

Downs, A. (1957). An Economic Theory of Democracy. Nowy Jork: Harper and Row. Elff, M. (2009). Political Knowledge in Comparative Perspective: The Problem of Cross-National Equivalence of Measurement. Referat przedstawiony na MPSA 2009 Annual National Conference, 2-5 kwietnia, Chicago.

Fishkin, J.S. (1997). The Voice of the People: Public Opinion and Democracy. New Haven: Yale University Press.

Galston, W.A. (2001). Political Knowledge, Political Engagement, and Civic Education. Annual Review of Political Science, 4, s. 217-234.

Galston, W.A. (2007). Civic Knowledge, Civic Education, and Civic Engagement: A Summary of Recent Research. International Journal of Public Administration, 30, s. 623-642.

Gilens, M. (2001). Political Ignorance and Collective Policy Preferences. American Political Science Review, 95, s. 379-396.

Grofman, B. (1995). Is Turnout the Paradox That Ate Rational Choice Theory? W: B. Grofman (red.), Information, Participation and Choice: An Economic Theory of Democracy in Perspective (s. 93-103). Ann Arbor: University of Michigan Press.

Hughes, J., Sasse, G., Gordon, C.E. (2004). Europeanization and Regionalization in the EU's Enlargement to Central and Eastern Europe: The Myth of Conditionality. New York: Palgrave Macmillan.

Kunovich, R.M. (2013). Political Knowledge in Poland. Electoral Studies, 46, s. 65-78. Lazarsfeld, P.F., Berelson, B.R., Gaudet, H. (1944). The People's Choice. Nowy Jork: Columbia University Press.

Linz, J., Stepan, A. (1996). Problems of Democratic Transition and Consolidation. Southern Europe, South America, and Post-communist Europe. Baltimore and London: The John Hopkins University Press.

Mannin, M. (1999). Pushing Back the Boundaries: the European Union and Central and Eastern Europe. Manchester: Manchester University Press.

Plutzer, E. (2002). Becoming a Habitual Voter: Inertia, Resources, and Growth in Young Adulthood. American Political Science Review, 96, s. 41-56. 
Rabinowitz, G., Macdonald, S.E. (1989). A Directional Theory of Issue Voting. American Political Science Review, 83, s. 93-121.

Raciborski, J. (2011). Obywatelstwo w perspektywie socjologicznej. Warszawa: Scholar. Raciborski, J. (red.). (2010). Praktyki obywatelskie Polaków. Warszawa: Wydawnictwo Instytutu Filozofii i Socjologii PAN.

Riker, W., Ordeshook, P. (1968). A Theory of the Calculus of Voting. American Political Science Review, 62, s. 25-43.

Sartori, G. (1994). Teoria demokracji. Warszawa: Wydawnictwo Naukowe PWN.

Schimmelfennig, F., Sedelmeier, U. (2005). The Europeanization of Central and Eastern Europe. Cornell: Cornell University Press.

Sedelmeier, U. (2005). Constructing the Path to Eastern Enlargement: the Uneven Policy Impact of EU Identity. Manchester: Manchester University Press.

Shively, P.W. (2001). Sztuka prowadzenia badań politycznych. Poznań: Zysk i S-ka.

Sissenich, B. (2007). Building States Without Society: European Union Enlargement and the Transfer of EU Social Policy to Poland and Hungary. Lanham: Lexington Books.

Toka, G., Popescu, M. (2008). Inequalities of Political Influence in New Democracies. International Journal of Sociology, 37, s. 67-93.

Tworzecki, H., Markowski, R. (2011). Wiedza a stronniczość partyjna - niełatwy związek. Studia Polityczne, 28, s. 87-112.

Zielonka, J. (2006). Europe as Empire. The Nature of the Enlarged European Union. Oxford: Oxford University Press.

Żerkowska-Balas, M. (2017). Czy głosowanie jest racjonalna decyzją? Warszawa: Scholar. 